\title{
Role of amyloid $\beta$ protein receptors in mediating synaptic plasticity (Review)
}

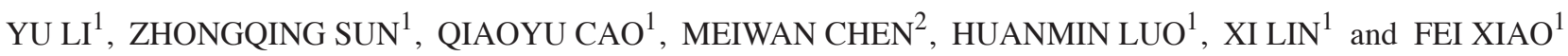 \\ ${ }^{1}$ Department of Pharmacology, School of Medicine, Jinan University, Guangzhou, \\ Guangdong 510632; ${ }^{2}$ State Key Laboratory of Quality Research in Chinese Medicine, \\ Institute of Chinese Medical Sciences, University of Macau, Macau 999078, P.R. China
}

Received October 26, 2016; Accepted December 1, 2016

DOI: $10.3892 /$ br.2017.863

\begin{abstract}
There are few diseases in modern biomedicine that have garnered as much scientific interest and public concern as Alzheimer's disease (AD). The amyloid hypothesis has become the dominant model of AD pathogenesis; however, the details of the hypothesis are changing over time. Recently, given the increasing recognition, subtle effects of amyloid $\beta$ protein $(\mathrm{A} \beta)$ on synaptic efficacy may be critical to AD progression. Synaptic plasticity is the important neurochemical foundation of learning and memory. Recent studies have identified that soluble $\mathrm{A} \beta$ oligomers combine with certain receptors to impair synaptic plasticity in AD, which advanced the amyloid hypothesis. The aim of the present review was to summarize the role of $A \beta$-relevant receptors in regulating synaptic plasticity and their downstream signaling cascades, which may provide novel insights into the understanding of the pathogenesis of AD and the development of therapeutic strategies to slow down the progression of AD-associated memory decline in the early stages.
\end{abstract}

\section{Contents}

1. Introduction

2. Association between synaptic plasticity and $A \beta$

3. A $\beta$-relevant receptors involved in regulating synaptic plasticity

4. Conclusion

Correspondence to: Professor Fei Xiao, Department of Pharmacology, School of Medicine, Jinan University, 601 West Huangpu Avenue, Guangzhou, Guangdong 510632, P.R. China E-mail: xiaofei@jnu.edu.cn

Key words: Alzheimer's disease, AD pathogenesis, amyloid $\beta$ protein, synaptic plasticity

\section{Introduction}

Alzheimer's disease (AD) is a chronic and progressive age-associated neurodegenerative disorder that represents $70 \%$ of all dementia, with 36 million cases worldwide. These cases may increase to 115 million by 2050 (1). Extracellular amyloid plaques composed of misfolded amyloid peptides and intracellular neurofibrillary tangles composed of hyperphosphorylated tau are the two characteristic pathologic features of AD (2). Memory loss and cognitive function decline are the early symptoms of $\mathrm{AD}$, which are due to the loss of synapses in the hippocampus and cortex (3). The amyloid hypothesis holds a dominant position in $\mathrm{AD}$ pathogenesis, which states that the accumulation of amyloid $\beta$ protein $(\mathrm{A} \beta)$ induces neuronal loss and cognitive impairments $(2,4)$. As scientists attempt to make this hypothesis more precise, neurotoxicity appears to be caused by diffusible oligomeric assemblies of $A \beta$, rather than mono- $\mathrm{A} \beta$ or the amyloid fibril protein. Currently, $\mathrm{AD}$ is considered to be a disease of synaptic failure; $A \beta$ interrupts the function of synapses that facilitated with encoding novel declarative memories $(5,6)$. Substantial evidence suggests that AD begins with subtle alterations of hippocampal synaptic efficacy, which is prior to neuronal degeneration, and that synaptic dysfunction is predominantly caused by diffusible oligomeric assemblies of $A \beta$ (7-9). Multiple lines of evidence indicate that there is an early, pre-plaque phase when learning and memory deficits are not detected in AD transgenic mice, although long-term potentiation (LTP) is already impaired $(5,6,10,11)$. Therefore, the change of synaptic plasticity induced by $A \beta$ may be the earliest non-clinical symptom of $\mathrm{AD}$, and may even occur in the high-risk population of AD. The abnormal levels of $A \beta$ mediate the change of synaptic plasticity to trigger the cascade reaction, which causes a gradual transition from an impairment of synaptic function to synaptic loss and subsequently cell apoptosis. Advances in molecular and cellular mechanisms underlying AD-associated synaptic dysfunction and memory deficits have been reported (12). However, to the best of our knowledge, the interaction of $A \beta$ and $A \beta$-relevant receptors and receptor-mediated synaptic plasticity damage have not been systematically clarified. In addition, synaptic plasticity is closely linked with other neurodegenerative diseases, nerve regeneration barriers, clinical depression, neuropathic pain and drug dependence. The elucidation of 
A $\beta$-relevant receptors in regulating synaptic plasticity will provide novel insights into the understanding of the pathogenesis of $\mathrm{AD}$ and novel therapeutic strategies to slow down the progression of $\mathrm{AD}$ at early stages, but also advances our understanding of the normal regulation of synaptic plasticity in learning and memory.

\section{Association between synaptic plasticity and A $\beta$}

Synaptic plasticity is the ability of synapses to strengthen or weaken over time in response to increases or decreases in their activity. LTP and long-term depression (LTD) are the primary performance models for synaptic plasticity. Synaptic plasticity is considered to be the mechanism of learning and memory. Numerous factors, such as glial cells, calcium ions and the neurotrophic factor family are key in regulating synaptic plasticity $(13,14)$.

$\mathrm{A} \beta$ is a protein produced by normal metabolism that is derived from amyloid precursor protein (APP) via sequential cleavage by $\beta$ - and $\gamma$-secretases (15-17). A $\beta$ possesses certain physiological functions, and early studies indicate that very low concentrations of soluble $A \beta$ promote neuronal survival and axonal branching, adjust the function of $\mathrm{K}^{+}$ion channels and are involved in the normal functioning of neurons. Much evidence suggests that the accumulation of $A \beta$ is a critical component of AD pathogenesis (18-20). Abnormal $\mathrm{A} \beta$ and the change of synaptic plasticity appear simultaneously during the early stage of AD. However, the association between synaptic plasticity and $A \beta$ is complicated. Recent studies indicate that synaptic activity regulates $A \beta$ levels in $\mathrm{AD}$, which are primarily associated with the regulation of APP endocytosis and cleavage. Glutamatergic, cholinergic, serotonergic, leptin, adrenergic, orexin, and gamma-amino butyric acid receptors, as well as the activity-regulated cytoskeleton-associated protein are all involved in these processes (21). A $\beta$ exists in numerous accumulation forms, including $A \beta$ monomer, $A \beta$ oligomers and $A \beta$ fibrils. The highest correlation of pathology associated with AD dementia is synapse loss, and the extent of synapse loss is associated with soluble $A \beta$ levels. Diffusible oligomeric assemblies of $A \beta$ cause synaptic dysfunction during the earliest processes of $\mathrm{AD}(5,22)$.

The soluble $\mathrm{A} \beta$ oligomers, with dimers being the smallest species, are necessary and sufficient to disrupt normal learning and memory function $(18,23,24)$. Previous studies $(13,25,26)$ indicate that dimers and trimers may be the early initiators of synapse failure, and that trimers are more potent in disrupting LTP than dimers $(26,27)$. In addition, previous studies suggest that soluble $A \beta$ oligomers induce the loss of LTP, increase LTD and decrease dendritic spine density in hippocampal slices $(18,25,28)$. N-methyl-D-aspartate receptors (NMDARs), mitochondrial reactive oxygen species, glycogen synthase kinase-3, and the mammalian target of rapamycin signaling pathways are reportedly involved in mediating the toxic effects of $A \beta$ on synaptic function (12). Multiple lines of evidence indicate that the deleterious effects of $A \beta$ prior to neuronal loss are mediated by NMDARs, particularly GluN2B-NMDARs (29). However, the molecular mechanism of $A \beta$ modulating synaptic plasticity via $A \beta$-relevant receptors has rarely been investigated.

\section{A $\beta$-relevant receptors involved in regulating synaptic plasticity}

$A \beta$ oligomers exert effects on synaptic plasticity and memory by binding to associated receptors and thereby activating downstream signaling $(30,31)$. The $A \beta$-associated receptors include cellular prion protein $\left(\mathrm{PrP}^{\mathrm{c}}\right)$, ephrin type $\mathrm{B}$ receptor 2 (EphB2), paired immunoglobulin (Ig)-like receptor B (PirB), IgG Fc $\gamma$ receptor II-B (Fc $\gamma$ RIIB), p75 neurotrophin receptor (p75NTR), and $\alpha 7$ nicotinic acetylcholine receptors (a7nAChRs). The aim of the present review was to evaluate the $A \beta$-associated receptors involved in modulating synaptic plasticity and receptor-mediated downstream signal transduction in regulating synaptic plasticity, which may lead to an effective target to prevent the pathologic process of $\mathrm{AD}$ during the early stages.

$\operatorname{PrP}^{c}$. Prion protein (PrP) exists in two forms: the cell form $\operatorname{PrP}\left(\mathrm{PrP}^{\mathrm{c}}\right)$ and the pathogenic form $\operatorname{PrP}\left(\mathrm{PrP}^{\mathrm{sc}}\right)$. The universal recognition of prion doctrine suggests that the normal prion protein, $\mathrm{PrP}^{\mathrm{c}}$ is converted into its abnormally-folded isoform, $\mathrm{PrP}^{\mathrm{Sc}}$ with protease resistance. $\mathrm{PrP}^{\mathrm{Sc}}$ further aggregates and deposits in the central nervous tissue and leads to certain pathological changes, including neurons loss, fibrous astrocytes hyperplasia and spongy degeneration. The types of degenerative brain disease includes transmissible spongiform encephalopathies and Creutzfeldt Jakob disease (CJD). CJD is caused by $\operatorname{PrP}^{\mathrm{sc}}$, which invades the central nervous system of humans, and has a long incubation period and poor prognosis. Although AD and CJD are different types of diseases, they belong to misfolded protein diseases, which are characterized by abnormal protein folding that translates the $\alpha$-helix into a beta sheet. This conformational change causes normal soluble proteins to change into insoluble protein polymers (32), and induces the pathology of protein aggregates. The former pathology is $A \beta$ deposition and the latter pathology is $\operatorname{PrP}{ }^{\mathrm{sc}}$ deposition.

$\operatorname{PrP}$ is expressed in almost all tissues, although $\operatorname{Pr}^{\mathrm{Pc}}$ is primarily distributed in the central nervous system. Recent research demonstrates that $\mathrm{PrP}^{\mathrm{c}}$ is involved in synaptic plasticity processes in the neonatal hippocampus (33). In addition, $\mathrm{PrP}^{\mathrm{c}}$ has been proposed as an additional possible mediator of oligomer action. PrPc binds synthetic $A \beta$ oligomers with high affinity and is involved in the oligomer-mediated inhibition of LTP (34). Laurén et al (35) injected A $\beta$ into mice and detected electrophysiological changes in the process of memory recovery. When injecting $\mathrm{A} \beta$ into a mouse with loss of $\operatorname{PrP}^{\mathrm{c}}$, no electrophysiological changes were observed. The study indicated that $\operatorname{PrP}^{\mathrm{c}}$ mediates synaptic plasticity damage caused by $\mathrm{A} \beta$ (35). Experiments in vivo demonstrate that $\operatorname{PrP}^{\mathrm{c}}$ and $\mathrm{A} \beta$ are co-localized, and in vitro experiments indicate that $\mathrm{PrPc}$ easily binds to $A \beta$ via fragments from 95 to 110 . The authors concluded that $\mathrm{PrP}^{\mathrm{c}}$ acts as a receptor and trigger a series of chain reactions, eventually leading to neuronal damage (35); however, Balducci et al (36) reported that mice injected with $\mathrm{A} \beta$ continued to suffer brain memory damage even in the absence of PrPc. In the study by Raeber et al (37), Aguzzi observed gene-engineered mice that produce a large number of A $\beta$, a phenomena similar to that of Balducci et al (36). Kessels et al (38) attempted to repeat the experiment by 
Laurén et al (35); and obtained a negative result. However, these studies do not deny the role of $\mathrm{PrP}^{\mathrm{c}}$, as the regulation of synaptic plasticity involves a complex network, and additional $\mathrm{A} \beta$-associated receptor-mediated changes in synaptic plasticity in $\mathrm{PrP}^{\mathrm{c}}$ knockout animals remain. Gimbel et al (39) reported that the absence of $\operatorname{PrP}^{c}$ eases memory damage of mice with an excessive accumulation of $\mathrm{A} \beta$. This finding supports the results of their previous research (40). Previously, in studies by An et al and $\mathrm{Hu}$ et al $(41,42)$ Rowan used antibodies to block PrPc to reduce the influence of $A \beta$ on electrophysiological changes associated with memory, which supports Strittmatter's conclusions [from the study by Gimbel et al (39)] at a conference on European neuroscience. Bitel et al (43) reported that $\mathrm{PrP}^{\mathrm{c}}$ and $\mathrm{A} \beta$ appeared as aggregates and co-localized in a diabetic rabbit model, which suggested that $\mathrm{A} \beta$ and $\operatorname{PrP}^{\mathrm{c}}$ may interact.

$\mathrm{A} \beta$ oligomers bind with $\mathrm{PrP}^{\mathrm{c}}$ receptors on the membrane, forming annular amyloid pores and membrane ion channels to induce aberrant spine cytoskeletal changes. However, the mechanism underlying the combination of $\operatorname{PrP}^{c}$ and $\mathrm{A} \beta$ requires investigation. Um et al (44) predicted the distribution, the specificity and possible activating signaling pathways of the $\mathrm{A} \beta-\mathrm{PrP}^{\mathrm{c}}$ complex, and whether this complex functions to regulate the NMDAR. Research has found that $\operatorname{PrP}^{c}$ predominantly aggregates in the postsynaptic density area (PSD) and the combination of $\mathrm{A} \beta-\mathrm{PrP}^{\mathrm{c}}$ may activate Fyn kinase, resulting in the phosphorylation of the NR2B subunits of NMDA, thus, reducing the number of NMDARs (44). Fyn also causes a lack of dendritic spines and the release of lactate dehydrogenase through $\mathrm{A} \beta$ interaction with $\mathrm{PrP}^{\mathrm{c}}$. This is consistent with recent reports that $\mathrm{A} \beta$ oligomers bind with $\mathrm{PrP}^{\mathrm{c}}$ on the membrane and form annular amyloid pores and membrane ion channels to induce aberrant spine cytoskeletal changes (45). The above-mentioned studies support that $\mathrm{A} \beta$ oligomers combined with $\mathrm{PrP}^{\mathrm{c}}$ activate Fyn kinase to cause the change of synaptic plasticity.

$E p h B 2$. Eph is predominantly distributed in the excitatory synapses and is the largest family of receptor tyrosine kinases, which primarily participates in the formation of tissue, and the occurrence of vascular and axon guidance in the growth process. In addition, Eph is important in the mature brain and participates in regulating synaptic plasticity (46). Furthermore, Eph is significant in the pathogenesis of AD.

EphB2, a member of the B subtype of Eph receptor tyrosine kinases, is a transmembrane protein, which has extracellular and intracellular structures that are highly conserved. Recent studies (47) indicate that the extracellular region of EphB2 comprises a ligand-binding (LB) domain, a cysteine-rich (CR) domain, and a fibronectin type III repeats (FN) domain. $\mathrm{A} \beta$ oligomers mainly bind to the FN domain of EphB2 and activate the degradation of the protease of EphB2 to deplete neuronal EphB2 by enhancing its proteasomal degradation. In addition, $\mathrm{A} \beta$ oligomers reduce EphB2 mRNA levels; however, the reduction is subtle and is unlikely to account for the severe EphB2 protein depletion. The A $\beta$-induced EphB2 depletion impairs synaptic plasticity. The proximal membrane region of the intracellular structure, composed of several conserved tyrosine residues, modulates the activity of the kinase domain. The tyrosine kinase domain (KD) is the predominant active region, the activation of which may occur by self-phosphorylation and phosphorylation of tyrosine residues of downstream substrate proteins, which then activate downstream signal transduction pathways, as sterile $\alpha$-motif mediates interactions among proteins, C-terminal PSD95, Drosophila disc large tumor suppressor, and zonula occludens-1 protein (PDZ) binding domain mediates the combination between kinase and proteins that contain the PDZ domain $(48,49)$.

Activity-dependent synaptic plasticity and memory formation require NMDA-type glutamate receptors expressed on the postsynaptic membrane of excitatory synapses (50). $\mathrm{Ca}^{2+}$ permeation of the NMDA receptor is crucial for synapse formation and the regulation of synaptic strength in adults (44). EphB2 was recently shown to interact with NMDARs at excitatory synapses $(51,52)$. Numerous experiments show that EphB2 receptors are required for the formation of forebrain commissures (53), retinal axon path finding (54), normal vestibular function (55), and the development of the vasculature (56). Further studies indicate that EphB2 receptors associate with NMDARs at synaptic sites and are involved in synaptogenesis. Grunwald et al (57) concluded that the EphB2 receptor is a kinase-independent receptor required in hippocampal synaptic plasticity by modulating signaling pathways implicated in synaptic plasticity and crosstalk with NMDAR-activated signaling pathways. The reduced expression level of EphB2 is associated with the impairment of synaptic plasticity. Grunwald et al (57) demonstrated that mice lacking EphB2 possessed normal hippocampal synapse morphology, but displayed defects in synaptic plasticity. Other studies reported that EphB2-deficient mice exhibited LTP deficits $(57,58)$. In the brain of AD transgenic mice, $\operatorname{Tg} 2575$, the expression level of EphB2 demonstrated an age-dependent regional decrease and a lower expression level of EphB2 was observed in the hippocampus. EphB2 plasmid overexpression in the dentate gyrus reversed the lower NMDAR-dependent LTP, and cure learning and memory impairment in hAPP transgenic mice.

EphB2 regulates glutamatergic neurotransmitter transmission via NMDAR (51); however, knowledge of the underlying mechanism of crosstalk of the EphB2/NMDAR signaling pathways remains limited. Studies show that EphB2 regulates NMDAR-dependent $\mathrm{Ca}^{2+}$ influx and downstream transcription factors involved in LTP formation (59). EphB2 is critical in mediating synaptic plasticity. The activation of EphB induces the phosphorylation of three Src kinase-dependent tyrosine residues of NR2B, which is critical for regulating expression levels of NMDAR in the synapses. The number of excitatory synapses decreases in mice with EphB1-3 three-gene knockout, while synaptic NMDAR currents are reduced in mice with only EphB2 gene knockout, and the LTP of the hippocampus is also inhibited (58). All of these results indicate that EphB2 has an important regulatory effect on synaptic NMDAR expression.

Soluble A $\beta$ oligomers influence synaptic plasticity by inhibiting NMDAR-dependent LTP, thus contributing to learning and memory deficits in AD $(18,60,61)$. Thus, $A \beta$ oligomers combine with the FN domain of EphB2 to cause EphB2 depletion and contribute to the impairment of synaptic plasticity, which is associated with the NMDAR. Cisse et al (47) found that an increased expression level of EphB2 improves the LTP of the dentate gyrus region, and promotes learning and 
memory capabilities. If this effect can be confirmed, drug treatment strategies will include improving the expression levels and activity of EphB2. The study by Cisse et al (47) also suggested that small molecules block $A \beta$ oligomers combined with the fibronectin type II repeat region of EphB2 or prevent the degradation of EphB2 protease, which may reduce the interaction between $A \beta$ and NMDAR.

PirB. PirB, also termed p91, is an immuno-inhibitory receptor first discovered by Kubagawa et al (62) from murine immune cells in 1997 and is similar to the Fc receptor for human IgA. PirB protein is a type I transmembrane glycoprotein, which has six Ig-like extracellular hydrophobic domains and four intracellular immunoreceptor tyrosine-based motif-like polypeptides. PirB recruits Src homology 1-containing protein tyrosine phosphatase or Src homology 2-containing protein tyrosine phosphatase, and improves immunosuppression. PirB is distributed in different hematopoietic cell lines, including B cells, mast cells, macrophages, granulocytes, dendritic cells, and is widely distributed at the surfaces of different neurons in the damaged central nervous system. Atwal et al (63) found that PirB is the second functional receptor for myelin inhibitors of axonal regeneration after the Nogo-66 receptor was first identified. Although PirB is the receptor for axon regeneration inhibitors, including Nogo, monoacylglycerol lipase and oligodendrocyte-myelin glycoprotein, the PirB-regulated molecular mechanism of axonal regeneration inhibition remains unclear. The human homolog of murine PirB is leukocyte Ig-like receptor B (LilrB2), which comprises five family members $(63,64)$. A recent study $(65)$ found that $A \beta_{42}$ oligomers are robustly bound to LilrB2-expressing heterologous cells, and LilrB2/PirB2 and A $\beta$ have an affinity at the nanomole level. Relative to monomeric $A \beta_{42}$, oligomerized $A \beta_{42}$ peptides are bound to PirB-expressing cells approximately six times as much. Kim et al (65) found that in AD mice, A $\beta$ oligomer damages the LTP of the hippocampus, which needs to combine with PirB. These studies suggest that PirB/LilrB2, as a receptor for $A \beta$ oligomers, are crucial for modulating synaptic plasticity. This effect may be via enhancing cofilin signaling to facilitate actin depolymerization, resulting in synaptic loss and ultimately leading to altered synaptic plasticity and cognitive deficits.

Increasing research shows that the downstream signaling associated with the effect of $A \beta$ to synaptic plasticity includes altering NMDAR function in response to $A \beta(35,44,47)$. The signaling pathways of the actin-severing protein, cofilin and protein phosphatases, PP2A and PP2B/calcineurin $(25,66)$ that signal upstream of these signaling pathways, including the interaction between $A \beta$ and PirB2/LilrB2, are not well understood. In addition, PirB mediates the dysfunction of learning and memory of adult mice in the transgenic mice AD model, and mediates the lack of synaptic plasticity in the visual cortex of young mice (65). Given the important role of $A \beta$ and PirB/LilrB2 in modulating synaptic plasticity, blocking the interaction of $A \beta$ and LilrB may be a promising target for treatment of $\mathrm{AD}$ even in the prodromal stage.

Fc4 IIB. Fc $\gamma \mathrm{R}$ belongs to the Ig superfamily and is a type of membrane glycoprotein that is predominantly expressed in the immune cell membranes of the hematopoietic system.
Certain $\mathrm{Fc} \gamma \mathrm{R}$ are expressed in the cell surface of histocytes, such as glomerular mesangial cells, follicular dendritic cells, microglial cells and osteoclasts organizations. Fc $\gamma$ RIIB, as a member of $\mathrm{Fc} \gamma \mathrm{R}$, is a type of IgG receptor. Fc $\gamma \mathrm{RIIB}$ initially combines with IgG to form immune complex-associated antigens and is expressed primarily in B cells, macrophages and neutrophils (67). Fc $\gamma$ RIIB is involved in inhibiting the B cell receptor-mediated immunoreactions and is also involved in autoimmune processes (68). A previous study demonstrated that Fc $\gamma$ RIIB gene knockout mice easily succumbed to autoimmune disease (69).

Recent studies (70) demonstrated that Fc $\gamma$ RIIB is important in the process of memory impairment and neurotoxicity caused by $A \beta$. Exogenously importing $A \beta$ to cortical neurons increases the expression of Fc $\gamma$ RIIB significantly. Kam et al (70) found the Fc $\gamma$ RIIB gene knockout neurons decreased LTD and the deficiency of synaptic function caused by $\mathrm{A} \beta$, and improved the memory ability of the AD model rats. Further research found that Fc $\gamma$ RIIB specifically combined with soluble $A \beta$ oligomers, causing the paralysis of synaptic function and the death of neurons, resulting in the abnormal behavior of rats (70). Fc $\gamma$ RIIB accelerated the process of memory ability impairments by activating neural immunity in the non-neurons from the AD rat model (71). Therefore, the passive immunization antagonism of $\mathrm{A} \beta$ has become a more desirable treatment strategy in the development of AD treatment therapeutic agents. However, the traditional passive immunity will often cause the immune response mediated by Fc $\gamma$ RIIB, activating the microglia, causing strong inflammatory reaction, and resulting in angioedema and cerebral hemorrhage. A previous study (72) identified that MABT5102A (MABT), a novel substance that combines with $\mathrm{A} \beta$ with high affinity and lowers the immune activity of Fc $\gamma$ RIIB, prevents the neurotoxicity induced by A $\beta$. In addition, Adolfsson et al (72) found that MABT reduced the formation of amyloid plaque in hAPP (V7171)/PS1 transgenic mice. Therefore, the in-depth analysis of Fc $\gamma$ RIIB identifies a novel strategy for the treatment of AD with a minimum level of immune response.

p75NTR. p75NTR, a member of the tumor necrosis factor receptor superfamily, is a low affinity neurotrophic factor receptor that interacts with a variety of ligands and causes different effects on the nervous system, including pro-survival or induction of apoptosis (73). Basal forebrain ganglia neurons express p75NTR, tropomyosin receptor kinase A (TrkA) and nerve growth factor (NGF); NGF as a neurotrophic factor, contributes to the growth and development of neural survival in the presence of TrkA. NGF combines with p75NTR to cause the phosphorylation of TrkA and activates the phosphoinositide 3-kinase/AKT signaling pathway (74). Endogenous NGF, brain-derived neurotrophic factor and other neurotrophins are involved in neuronal survival, synaptic regeneration, and improvement of cognitive impairment though the p75NTR signaling pathway.

In the pathological process of neurodegenerative disease, p75NTR combined with extracellular receptors, such as A $\beta$ and myelin-associated inhibitory factors, contributes to axonal regeneration inhibition and synaptic dysfunction by activating the downstream signaling pathway. Recent studies demonstrate that in the absence of APP, NGF treatment may preferentially 
direct p75-neurotrophin-dependent c-Jun N-terminal kinase activation toward regeneration and plasticity in functionally relevant brain circuits $(75)$.

As a result of the above-mentioned findings, the present study hypothesizes that p75NTR exerts a double-sided regulating function in synaptic plasticity. Under physiological conditions, p75NTR maintains the synaptic plasticity together with TrkA and NGF. Furthermore, as a receptor of $\mathrm{A} \beta$, p75NTR is crucial in impairing synaptic plasticity by binding with $\mathrm{A} \beta$ in pathological conditions.

Yaar et al (76) found that the annular antagonist peptide of p75NTR competitively combines with p75NTR by competing with $A \beta$, thus inhibiting neurotoxicity caused by $\mathrm{A} \beta$ in vitro. Stereotaxic injection of p75NTR annular antagonism peptides into the rat cortex specifically combine with $A \beta$, thus abating the inflammation and neurotoxicity caused by $A \beta$ (77). Certain non-protein small molecule compounds combine with p75NTR and inhibit the A $\beta$-induced impairments in synaptic plasticity. Studies found that $A \beta$ stimulates the expression of p75NTR in cell culture systems and in the brain of AD transgenic mouse (particularly in the hippocampus) $(78,79)$, which indicates that $A \beta$ unregulated P75NTR expression in the brain. A previous study indicated that p75NTR expression levels may serve as markers of normal aging and AD (80); p75NTR expression is upregulated and the expression level of TrkA is reduced with increasing age. Furthermore, activation of the p75NTR signaling pathway increases the expression level of $\beta$-secretase 1 and accelerates $A \beta$ accumulation (77). In APPswe/PS1 transgenic rats, gene knockout of p75NTR contributed to the decrease of $\mathrm{A} \beta$ in the cerebral cortex, indicating that the $\mathrm{p} 75 \mathrm{NTR}$ signaling pathways promote the generation of $A \beta$ (81). Thus, $A \beta$ and p75NTR form a positive feedback and further accelerate the damage of synaptic plasticity. However, the extracellular fragment of soluble p75NTR, released by a neuron, inhibits $A \beta$ aggregation and promotes $A \beta$ clearance, resulting in opposite regulation of $A \beta$ deposition $(80,82)$. Previous studies reported that in the AD brain, p75NTR mediated neuronal degeneration and neuronal death $(83,84)$, and participated in the neuronal cell cycle and consumption of neural stem cells $(80,85)$. Thus, p75NTR has an important and complicated role in regulating synaptic plasticity, generation of $\mathrm{A} \beta$ and neuronal survival of $\mathrm{AD}$.

$\alpha 7 n A C h R s . n A C h R s$ are included in the large family of ligand-gated ionotropic receptors. They are activated by exogenous nicotine and endogenous acetylcholine (ACh) and define a cation-selective permeability across the plasma membrane of neurons and non-neural cells (86). Their functional properties result from the specific structure of subunit composition. In vertebrates, there are nine $\alpha(\alpha 2-\alpha 10)$ and three $\beta(\beta 2-\beta 4)$ subunits that are genetically distinct and combine to form heteromeric or homomeric pentamers in the cell membrane (87). Nicotinic receptors expressed on neurons are represented by homomeric pentamers consisting of $\alpha 7, \alpha 8$ and $\alpha 10$ subunits, and heteromeric receptors consisting of $\alpha 7$, $\alpha 8$ and/or $\alpha 10$ subunits, $\alpha 2-\alpha 6$ and $\beta 2-\beta 4$ subunits, in different combinations. In situ hybridization studies demonstrated that homomeric $\alpha 7$, containing $\alpha 7 \mathrm{nAChRs,} \mathrm{are} \mathrm{highly} \mathrm{expressed}$ in the cortex, hippocampus and subcortical areas, such as the basal ganglia, thalamus and limbic regions $(88,89)$.
The functional location of $\alpha 7 \mathrm{nAChRs}$ in the hippocampus indicates the involvement of these receptors in memory formation, and LTP and LTD are proposed to be regulated by cholinergic transmission (90-92). Currently, $\alpha 7 \mathrm{nAChR}$ is proven to be an $A \beta_{42}$ receptor. $A \beta_{42}$ activates the extracellular signal-regulated kinase (ERK2) isoform of the ERK mitogen-activated protein kinase (MAPK) cascade via $\alpha 7$ nAChRs, activation of this kinase in the hippocampus is required for contextual and spatial memory formation in mammals (93-96). The cAMP-regulatory element binding protein is the downstream target of ERK/MAPK and is also a necessary component for hippocampus-dependent memory formation in mammals (97). The ERK2/MAPK cascade is known to be critical in hippocampus synaptic plasticity and learning. Furthermore, the ERK/MAPK cascade has been implicated in regulating $A \beta$ production in neurons (98). One of the effects of downregulated ERK2/MAPK activity may be the creation of a positive feedback loop for $A \beta$ accumulation. $\alpha 7 \mathrm{nAChR}$ couple $\mathrm{A} \beta_{42}$ to the ERK/MAPK cascade, resulting in the impairment of synaptic plasticity in the hippocampus. Previously, $\alpha 7 \mathrm{nAChRs}$ have been demonstrated to be specifically involved in visual cortex synaptic plasticity (99). Overall, these findings highlight a potential therapeutic target of $\alpha 7 \mathrm{nAChR}$ for reversing the impairment of synaptic plasticity.

\section{Conclusion}

In conclusion, $\mathrm{A} \beta$-induced impairment of synaptic plasticity is hypothesized to be the initial and prominent motivator in the pathological process of AD and contributes to a novel version of the amyloid hypothesis. The interaction between $\mathrm{A} \beta$ and $\mathrm{A} \beta$-binding receptors and the associated mechanisms regulating synaptic plasticity are not fully understood. In addition to binding to $\mathrm{A} \beta$, these receptors bind to other vital ligand proteins to exert vital physiological effects, such as tissue patterning, angiogenesis, axon guidance and anti-apoptosis. The majority of these receptors appear to have certain common features, which cause a preference to bind with $A \beta$ oligomers. As $A \beta$ oligomers are diverse and complex, it remains unclear which types of $A \beta$ oligomers (dimer, trimer or tetramer) prefer to combine with receptors. The details of the interaction between $A \beta$ oligomers and these receptors remain unknown. Furthermore, whether the effect of these receptors in modulating synaptic plasticity is equal or whether one or two receptors are particularly key in synaptic plasticity of AD remains unclear. Further in-depth research is required to clarify the separate signaling pathways and complex crosstalk, which would contribute to a profound understanding of the function of $A \beta$ in synaptic plasticity. This may lead to a novel target in blocking or even reversing the pathological process of $\mathrm{AD}$ during the early or even prodromal stage.

\section{Acknowledgements}

The present study was funded by the Natural Science Foundation of China (grant nos. 81202519 and 81403120), and supported by the Science and Technology Program of Guangzhou (grant nos. 201607010216 and 201510010074) and 
the Science and Technology Planning Project of Guangdong Province (grant nos. 2014A010105029 and 2014A020211022).

\section{References}

1. Brambilla D, Le Droumaguet B, Nicolas J, Hashemi SH, Wu LP, Moghimi SM, Couvreur P and Andrieux K: Nanotechnologies for Alzheimer's disease: Diagnosis, therapy, and safety issues. Nanomedicine 7: 521-540, 2011.

2. Selkoe DJ and Hardy J: The amyloid hypothesis of Alzheimer's disease at 25 years. EMBO Mol Med 8: 595-608, 2016.

3. Oddo S, Caccamo A, Shepherd JD, Murphy MP, Golde TE, Kayed R, Metherate R, Mattson MP, Akbari Y and LaFerla FM: Triple-transgenic model of Alzheimer's disease with plaques and tangles: Intracellular Abeta and synaptic dysfunction. Neuron 39: 409-421, 2003.

4. Glenner GG and Wong CW: Alzheimer's disease: initial report of the purification ans characterization of a novel cerebrovascular amyloidprotein. Biochem Biophys Res Commun 425: 534-539, 2012.

5. Selkoe DJ: Alzheimer's disease is a synaptic failure. Science 298: 789-791, 2002

6. Audrain M, Fol R, Dutar P, Potier B, Billard JM, Flament J, Alves S, Burlot MA, Dufayet-Chaffaud G, Bemelmans AP, et al: Alzheimer's disease-like APP processing in wild-type mice identifies synaptic defects as initial steps of disease progression. Mol Neurodegener 11: 5, 2016.

7. Lacor PN: Advances on the understanding of the origins of synaptic pathology in AD. Curr Genomics 8: 486-508, 2007.

8. Terry RD: Cell death or synaptic loss in Alzheimer disease. J Neuropathol Exp Neurol 59: 1118-1119, 2000.

9. Scheff SW, Price DA, Schmitt FA, DeKosky ST and Mufson EJ: Synaptic alterations in CA1 in mild Alzheimer disease and mild cognitive impairment. Neurology 68: 1501-1508, 2007.

10. Jacobsen JS, WuCC,RedwineJM,ComeryTA, AriasR,Bowlby M, Martone R, Morrison JH, Pangalos MN, Reinhart PH, et al: Early-onset behavioral and synaptic deficits in a mouse model of Alzheimer's disease. Proc Natl Acad Sci USA 103: 5161-5166, 2006.

11. Ma T, Hoeffer CA, Capetillo-Zarate E, Yu F, Wong H, Lin MT, Tampellini D, Klann E, Blitzer RD and Gouras GK: Dysregulation of the mTOR pathway mediates impairment of synaptic plasticity in a mouse model of Alzheimer's disease. PLoS One 5: e12845, 2010.

12. Ma T and Klann E: Amyloid $\beta$ : Linking synaptic plasticity failure to memory disruption in Alzheimer's disease. J Neurochem 120 (Suppl 1): 140-148, 2012.

13. Malenka RC: The long-term potential of LTP. Nat Rev Neurosci 4: 923-926, 2003

14. Kandel ER: The molecular biology of memory storage: A dialog between genes and synapses. Biosci Rep 21: 565-611, 2001.

15. Esch FS, Keim PS, Beattie EC, Blacher RW, Culwell AR, Oltersdorf T, McClure D and Ward PJ: Cleavage of amyloid beta peptide during constitutive processing of its precursor. Science 248: 1122-1124, 1990.

16. Kang J, Lemaire HG, Unterbeck A, Salbaum JM, Masters CL, Grzeschik KH, Multhaup G, Beyreuther K and Müller-Hill B: The precursor of Alzheimer's disease amyloid A4 protein resembles a cell-surface receptor. Nature 325: 733-736, 1987.

17. Selkoe DJ: The cell biology of beta-amyloid precursor protein and presenilin in Alzheimer's disease. Trends Cell Biol 8: 447-453, 1998.

18. Shankar GM, Li S, Mehta TH, Garcia-Munoz A, Shepardson NE, Smith I, Brett FM, Farrell MA, Rowan MJ, Lemere CA, et al: Amyloid-beta protein dimers isolated directly from Alzheimer's brains impair synaptic plasticity and memory. Nat Med 14 837-842, 2008.

19. Walsh DM, Klyubin I, Shankar GM, Townsend M, Fadeeva JV, Betts V, Podlisny MB, Cleary JP, Ashe KH, Rowan MJ, et al: The role of cell-derived oligomers of Abeta in Alzheimer's disease and avenues for therapeutic intervention. Biochem Soc Trans 33: 1087-1090, 2005.

20. Hardy J and Selkoe DJ: The amyloid hypothesis of Alzheimer's disease: Progress and problems on the road to therapeutics. Science 297: 353-356, 2002.

21. Cheng X, Wu J, Geng M and Xiong J: Role of synaptic activity in the regulation of amyloid beta levels in Alzheimer's disease. Neurobiol Aging 35: 1217-1232, 2014
22. Stéphan A and Phillips AG: A case for a non-transgenic animal model of Alzheimer's disease. Genes Brain Behav 4: 157-172, 2005.

23. Lesné S, Koh MT, Kotilinek L, Kayed R, Glabe CG, Yang A, Gallagher M and Ashe KH: A specific amyloid-beta protein assembly in the brain impairs memory. Nature 440: 352-357, 2006.

24. Cleary JP, Walsh DM, Hofmeister JJ, Shankar GM, Kuskowski MA, Selkoe DJ and Ashe KH: Natural oligomers of the amyloid-beta protein specifically disrupt cognitive function. Nat Neurosci 8: 79-84, 2005.

25. Shankar GM, Bloodgood BL, Townsend M, Walsh DM, Selkoe DJ and Sabatini BL: Natural oligomers of the Alzheimer amyloid-beta protein induce reversible synapse loss by modulating an NMDA-type glutamate receptor-dependent signaling pathway. J Neurosci 27: 2866-2875, 2007.

26. Selkoe DJ: Soluble oligomers of the amyloid beta-protein impair synaptic plasticity and behavior. Behav Brain Res 192: 106-113, 2008.

27. Townsend M, Shankar GM, Mehta T, Walsh DM and Selkoe DJ: Effects of secreted oligomers of amyloid beta-protein on hippocampal synaptic plasticity: A potent role for trimers. J Physiol 572: 477-492, 2006.

28. Hsieh H, Boehm J, Sato C, Iwatsubo T, Tomita T, Sisodia S and Malinow R: AMPAR removal underlies Abeta-induced synaptic depression and dendritic spine loss. Neuron 52: 831-843, 2006.

29. Hanson JE, Pare JF, Deng L, Smith Y and Zhou Q: Altered GluN2B NMDA receptor function and synaptic plasticity during early pathology in the PS2APP mouse model of Alzheimer's disease. Neurobiol Dis 74: 254-262, 2015.

30. Jarosz-Griffiths HH, Noble E, Rushworth JV and Hooper NM: Amyloid- $\beta$ Receptors: The Good, the Bad, and the Prion Protein. J Biol Chem 291: 3174-3183, 2016.

31. Xia M, Cheng X, Yi R, Gao D and Xiong J: The Binding Receptors of A $\beta$ : An Alternative Therapeutic Target for Alzheimer's Disease. Mol Neurobiol 53: 455-471, 2016.

32. Carrell RW and Gooptu B: Conformational changes and disease - serpins, prions and Alzheimer's. Curr Opin Struct Biol 8: 799-809, 1998.

33. Caiati MD, Safiulina VF, Fattorini G, Sivakumaran S, Legname $\mathrm{G}$ and Cherubini E: PrPC controls via protein kinase A the direction of synaptic plasticity in the immature hippocampus. J Neurosci 33: 2973-2983, 2013.

34. Glatzel M, Abela E, Maissen M and Aguzzi A: Extraneural pathologic prion protein in sporadic Creutzfeldt-Jakob disease. N Engl J Med 349: 1812-1820, 2003.

35. Laurén J, Gimbel DA, Nygaard HB, Gilbert JW and Strittmatter SM: Cellular prion protein mediates impairment of synaptic plasticity by amyloid-beta oligomers. Nature 457: 1128-1132, 2009.

36. Balducci C, Beeg M, Stravalaci M, Bastone A, Sclip A, Biasini E, Tapella L, Colombo L, Manzoni C, Borsello T, et al: Synthetic amyloid-beta oligomers impair long-term memory independently of cellular prion protein. Proc Natl Acad Sci USA 107: 2295-2300, 2010.

37. Raeber AJ, Sailer A, Hegyi I, Klein MA, Rülicke T, Fischer M, Brandner S, Aguzzi A and Weissmann C: Ectopic expression of prion protein (PrP) in T lymphocytes or hepatocytes of PrP knockout mice is insufficient to sustain prion replication. Proc Natl Acad Sci USA 96: 3987-3992, 1999.

38. Kessels HW, Nguyen LN, Nabavi S and Malinow R: The prion protein as a receptor for amyloid beta. Nature 466: E3-E4, 2010.

39. Gimbel DA, Nygaard HB, Coffey EE, Gunther EC, Laurén J, Gimbel ZA and Strittmatter SM: Memory impairment in transgenic Alzheimer mice requires cellular prion protein. J Neurosci 30: 6367-6374, 2010.

40. Benilova I and De Strooper B: Prion protein in Alzheimer's pathogenesis: A hot and controversial issue. EMBO Mol Med 2: 289-290, 2010.

41. An K, Klyubin I, Kim Y, Jung JH, Mably AJ, O'Dowd ST, Lynch T, Kanmert D, Lemere CA, Finan GM, et al: Exosomes neutralize synaptic-plasticity-disrupting activity of $\mathrm{A} \beta$ assemblies in vivo. Mol Brain 6: 47, 2013.

42. Hu NW, Nicoll AJ, Zhang D, Mably AJ, O'Malley T, Purro SA, Terry C, Collinge J, Walsh DM and Rowan MJ: mGlu5 receptors and cellular prion protein mediate amyloid- $\beta$-facilitated synaptic long-term depression in vivo. Nat Commun 5: 3374, 2014.

43. Bitel CL, Feng Y, Souayah N and Frederikse PH: Increased expression and local accumulation of the prion protein, Alzheimer $\mathrm{A} \beta$ peptides, superoxide dismutase 1 , and nitric oxide synthases $1 \& 2$ in muscle in a rabbit model of diabetes. BMC Physiol 10: 18, 2010. 
44. Um JW, Nygaard HB, Heiss JK, Kostylev MA, Stagi M, Vortmeyer A, Wisniewski T, Gunther EC and Strittmatter SM: Alzheimer amyloid- $\beta$ oligomer bound to postsynaptic prion protein activates Fyn to impair neurons. Nat Neurosci 15: $1227-1235,2012$.

45. Sivanesan S, Tan A and Rajadas J: Pathogenesis of Abeta oligomers in synaptic failure. Curr Alzheimer Res 10: 316-323, 2013.

46. Gerlai R: Eph receptors and neural plasticity. Nat Rev Neurosci 2: 205-209, 2001.

47. Cissé M, Halabisky B, Harris J, Devidze N, Dubal DB, Sun B Orr A, Lotz G, Kim DH, Hamto P, et al: Reversing EphB2 depletion rescues cognitive functions in Alzheimer model. Nature 469: 47-52, 2011.

48. Kullander K and Klein R: Mechanisms and functions of Eph and ephrin signalling. Nat Rev Mol Cell Biol 3: 475-486, 2002.

49. Yamaguchi $Y$ and Pasquale EB: Eph receptors in the adult brain Curr Opin Neurobiol 14: 288-296, 2004.

50. Bliss TV and Collingridge GL: A synaptic model of memory: Long-term potentiation in the hippocampus. Nature 361: 31-39, 1993.

51. Dalva MB, Takasu MA, Lin MZ, Shamah SM, Hu L, Gale NW and Greenberg ME: EphB receptors interact with NMDA receptors and regulate excitatory synapse formation. Cell 103: 945-956, 2000.

52. Drescher U: Excitation at the synapse: Eph receptors team up with NMDA receptors. Cell 103: 1005-1008, 2000.

53. Henkemeyer M, Orioli D, Henderson JT, Saxton TM, Roder J, Pawson T and Klein R: Nuk controls pathfinding of commissural axons in the mammalian central nervous system. Cell 86: 35-46, 1996.

54. Birgbauer E, Cowan CA, Sretavan DW and Henkemeyer M: Kinase independent function of EphB receptors in retinal axon pathfinding to the optic disc from dorsal but not ventral retina. Development 127: 1231-1241,2000.

55. Cowan CA, Yokoyama N, Bianchi LM, Henkemeyer M and Fritzsch B: EphB2 guides axons at the midline and is necessary for normal vestibular function. Neuron 26: 417-430, 2000.

56. Adams RH, Wilkinson GA, Weiss C, Diella F, Gale NW, Deutsch U, Risau W and Klein R: Roles of ephrinB ligands and EphB receptors in cardiovascular development: Demarcation of arterial/venous domains, vascular morphogenesis, and sprouting angiogenesis. Genes Dev 13: 295-306, 1999.

57. Grunwald IC, Korte M, Wolfer D, Wilkinson GA, Unsicker K, Lipp HP, Bonhoeffer T and Klein R: Kinase-independent requirement of EphB2 receptors in hippocampal synaptic plasticity. Neuron 32: 1027-1040, 2001.

58. Henderson JT, Georgiou J, Jia Z, Robertson J, Elowe S, Roder JC and Pawson T: The receptor tyrosine kinase EphB2 regulates NMDA-dependent synaptic function. Neuron 32: 1041-1056, 2001.

59. Takasu MA, Dalva MB, Zigmond RE and Greenberg ME: Modulation of NMDA receptor-dependent calcium influx and gene expression through EphB receptors. Science 295: 491-495, 2002

60. Walsh DM and Selkoe DJ: Deciphering the molecular basis of memory failure in Alzheimer's disease. Neuron 44: 181-193, 2004.

61. Kamenetz F, Tomita T, Hsieh H, Seabrook G, Borchelt D, Iwatsubo T, Sisodia S and Malinow R: APP processing and synaptic function. Neuron 37: 925-937, 2003.

62. Kubagawa H, Burrows PD and Cooper MD: A novel pair of immunoglobulin-like receptors expressed by B cells and myeloid cells. Proc Natl Acad Sci USA 94: 5261-5266, 1997.

63. Atwal JK, Pinkston-Gosse J, Syken J, Stawicki S, Wu Y, Shatz C and Tessier-Lavigne M: PirB is a functional receptor for myelin inhibitors of axonal regeneration. Science 322: 967-970, 2008.

64. Takai T: Paired immunoglobulin-like receptors and their MHC class I recognition. Immunology 115: 433-440, 2005.

65. Kim T, Vidal GS, Djurisic M, William CM, Birnbaum ME, Garcia KC, Hyman BT and Shatz CJ: Human LilrB2 is a $\beta$-amyloid receptor and its murine homolog PirB regulates synaptic plasticity in an Alzheimer's model. Science 341: 1399-1404, 2013

66. Wang X, Takata T, Bai X, Ou F, Yokono K and Sakurai T: Pyruvate prevents the inhibition of the long-term potentiation induced by amyloid- $\beta$ through protein phosphatase $2 \mathrm{~A}$ inactivation. J Alzheimers Dis 30: 665-673, 2012.

67. Lehmann B, Schwab I, Böhm S, Lux A, Biburger $M$ and Nimmerjahn F: Fc $\gamma$ RIIB: A modulator of cell activation and humoral tolerance. Expert Rev Clin Immunol 8: 243-254, 2012.
68. Baerenwaldt $A$ and Nimmerjahn F: Immune regulation: FcgammaRIIB - regulating the balance between protective and autoreactive immune responses. Immunol Cell Biol 86: 482-484, 2008.

69. Bolland S and Ravetch JV: Spontaneous autoimmune disease in $\mathrm{Fc}$ (gamma)RIIB-deficient mice results from strain-specific epistasis. Immunity 13: 277-285, 2000.

70. Kam TI, Song S, Gwon Y, Park H, Yan JJ, Im I, Choi JW, Choi TY, Kim J, Song DK, et al: Fc $\gamma$ RIIb mediates amyloid- $\beta$ neurotoxicity and memory impairment in Alzheimer's disease. J Clin Invest 123: 2791-2802, 2013.

71. Fearon DT: The complement system and adaptive immunity. Semin Immunol 10: 355-361, 1998

72. Adolfsson O, Pihlgren M, Toni N, Varisco Y, Buccarello AL, AntonielloK,LohmannS,Piorkowska K, Gafner V,Atwal JK, et al: An effector-reduced anti- $\beta$-amyloid $(\mathrm{A} \beta)$ antibody with unique $\mathrm{a} \beta$ binding properties promotes neuroprotection and glial engulfment of A $\beta$. J Neurosci 32: 9677-9689, 2012

73. Chen Y, Zeng J, Cen L, Chen Y, Wang X, Yao G, Wang W, Qi W and Kong K: Multiple roles of the p75 neurotrophin receptor in the nervous system. J Int Med Res 37: 281-288, 2009.

74. Roux PP, Bhakar AL, Kennedy TE and Barker PA: The p75 neurotrophin receptor activates Akt (protein kinase B) through a phosphatidylinositol 3-kinase-dependent pathway. J Biol Chem 276: 23097-23104, 2001.

75. La Rosa LR, Matrone C, Ferraina C, Panico MB, Piccirilli S, Di Certo MG, Strimpakos G, Mercuri NB, Calissano P, D'Amelio M, et al: Age-related changes of hippocampal synaptic plasticity in A $\beta P P-n u l l$ mice are restored by NGF through p75NTR. J Alzheimers Dis 33: 265-272, 2013.

76. Yaar M, Zhai S, Panova I, Fine RE, Eisenhauer PB, Blusztajn JK, Lopez-Coviella I and Gilchrest BA: A cyclic peptide that binds p75(NTR) protects neurones from beta amyloid (1-40)-induced cell death. Neuropathol Appl Neurobiol 33: 533-543, 2007.

77. Yaar M, Arble BL, Stewart KB, Qureshi NH, Kowall NW and Gilchrest BA: p75NTR antagonistic cyclic peptide decreases the size of beta amyloid-induced brain inflammation. Cell Mol Neurobiol 28: 1027-1031, 2008

78. Chakravarthy B, Gaudet C, Ménard M, Atkinson T, Brown L, Laferla FM, Armato U and Whitfield J: Amyloid-beta peptides stimulate the expression of the p75(NTR) neurotrophin receptor in SHSY5Y human neuroblastoma cells and AD transgenic mice. J Alzheimers Dis 19: 915-925, 2010.

79. Perez SE, He B, Muhammad N, Oh KJ, Fahnestock M, Ikonomovic MD and Mufson EJ: Cholinotrophic basal forebrain system alterations in 3xTg-AD transgenic mice. Neurobiol Dis 41: 338-352, 2011

80. Zeng F, Lu JJ, Zhou XF and Wang YJ: Roles of p75NTR in the pathogenesis of Alzheimer's disease: A novel therapeutic target. Biochem Pharmacol 82: 1500-1509, 2011.

81. Wang YJ, Wang X, Lu JJ, Li QX, Gao CY, Liu XH, Sun Y, Yang M, Lim Y, Evin G, et al: p75NTR regulates Abeta deposition by increasing Abeta production but inhibiting Abeta aggregation with its extracellular domain. J Neurosci 31: 2292-2304, 2011.

82. Zhou XF and Wang YJ: The p75NTR extracellular domain: A potential molecule regulating the solubility and removal of amyloid- $\beta$. Prion 5: 161-163, 2011.

83. Costantini C, Rossi F, Formaggio E, Bernardoni R, Cecconi D and Della-Bianca V: Characterization of the signaling pathway downstream p75 neurotrophin receptor involved in beta-amyloid peptide-dependent cell death. J Mol Neurosci 25: 141-156, 2005.

84. Knowles JK, Rajadas J, Nguyen TV, Yang T, LeMieux MC, Vander Griend L, Ishikawa C, Massa SM, Wyss-Coray T and Longo FM: The p75 neurotrophin receptor promotes amyloid-beta(1-42)-induced neuritic dystrophy in vitro and in vivo. J Neurosci 29: 10627-10637, 2009.

85. Frade JM and López-Sánchez N: A novel hypothesis for Alzheimer disease based on neuronal tetraploidy induced by $\mathrm{p} 75$ (NTR). Cell Cycle 9: 1934-1941, 2010.

86. Le Novere $\mathrm{N}$ and Changeux JP: Molecular evolution of the nicotinic acetylcholine receptor: an example of multigene family in excitable cells. J Mol Evol 40: 155-172, 1995.

87. Nai Q, McIntosh JM and Margiotta JF: Relating neuronal nicotinic acetylcholine receptor subtypes defined by subunit composition and channel function. Mol Pharmacol 63: 311-324, 2003.

88. Hogg RC, Raggenbass M and Bertrand D: Nicotinic acetylcholine receptors: From structure to brain function. Rev Physiol Biochem Pharmacol 147: 1-46, 2003.

89. Albuquerque EX, Pereira EF, Alkondon M and Rogers SW: Mammalian nicotinic acetylcholine receptors: From structure to function. Physiol Rev 89: 73-120, 2009. 
90. Perry EK, Morris CM, Court JA, Cheng A, Fairbairn AF, McKeith IG, Irving D, Brown A and Perry RH: Alteration in nicotine binding sites in Parkinson's disease, Lewy body dementia and Alzheimer's disease: Possible index of early neuropathology. Neuroscience 64: 385-395, 1995.

91. Frazier CJ, Rollins YD, Breese CR, Leonard S, Freedman R and Dunwiddie TV: Acetylcholine activates an alpha-bungarotoxin-sensitive nicotinic current in rat hippocampal interneurons, but not pyramidal cells. J Neurosci 18: 1187-1195, 1998.

92. McQuiston AR and Madison DV: Nicotinic receptor activation excites distinct subtypes of interneurons in the rat hippocampus. J Neurosci 19: 2887-2896, 1999.

93. Blum S, Moore AN, Adams F and Dash PK: A mitogen-activated protein kinase cascade in the CA1/CA2 subfield of the dorsal hippocampus is essential for long-term spatial memory. J Neurosci 19: 3535-3544, 1999.

94. Selcher JC, Atkins CM, Trzaskos JM, Paylor R and Sweatt JD: A necessity for MAP kinase activation in mammalian spatial learning. Learn Mem 6: 478-490, 1999.
95. Schafe GE, Nadel NV, Sullivan GM, Harris A and LeDoux JE: Memory consolidation for contextual and auditory fear conditioning is dependent on protein synthesis, PKA, and MAP kinase. Learn Mem 6: 97-110, 1999.

96. Atkins CM, Selcher JC, Petraitis JJ, Trzaskos JM and Sweatt JD: The MAPK cascade is required for mammalian associative learning. Nat Neurosci 1: 602-609, 1998.

97. Bourtchuladze R, Frenguelli B, Blendy J, Cioffi D, Schutz G and Silva AJ: Deficient long-term memory in mice with a targeted mutation of the cAMP-responsive element-binding protein. Cell 79: 59-68, 1994.

98. Mills J, Laurent Charest D, Lam F, Beyreuther K, Ida N, Pelech SL and Reiner PB: Regulation of amyloid precursor protein catabolism involves the mitogen-activated protein kinase signal transduction pathway. J Neurosci 17: 9415-9422, 1997.

99. Criscuolo C, Accorroni A, Domenici L and Origlia N: Impaired synaptic plasticity in the visual cortex of mice lacking $\alpha 7$-nicotinic receptor subunit. Neuroscience 294: 166-171, 2015. 